Al-Uqud: Journal of Islamic Economics

Volume 4 Issue 1, January 2020

E-ISSN 2548-3544, P-ISSN 2549-0850

DOI:10.26740/al-uqud.v4n1.p1-17

Accredited No. 28/E/KPT/2019

Page 1-17

\title{
Determinants of Customer Preference to Save in Islamic Bank
}

\author{
Tia Afriani ${ }^{1}$, Nadia Asandimitra ${ }^{2 *}$ \\ 1,2Department of Management, Faculty of Economics, Universitas Negeri Surabaya \\ Jalan Ketintang, Surabaya 60231, Indonesia
}

\begin{abstract}
The widespread use of sharia products and instruments encourages society to save funds in sharia banks. The main purpose of this research is to test the effect of financial literacy, profit sharing, knowledge of customers, gender, age, education, income to saving decisions. The type of research is quantitative research by using a non-probability sampling method with snowball sampling and purposive sampling technique to get a sample of 230 respondents. The object of this research was sharia bank's customers in Surabaya. The data obtained by spreading the questionnaire online and offline contains 41 items of statement and question. The data analysis technique is multiple linear regression that calculated by software package used for the analysis of statistical data. The result found that financial literacy's of customer has medium effect about $72.1 \%$ to their saving decision. The higher level of customer's financial literacy increases their ability to manage finance and saving. Meanwhile, profit-sharing has an effect to saving decision, as the higher level of profit sharing will raise society's interest for saving in sharia bank. Otherwise, customer knowledge and demographic factors (gender, age, education and income) have no effect to their saving decision.
\end{abstract}

Keywords: Customer knowledge; Demographic factors; Financial literacy; Profitsharing; Saving decision; Islamic bank

Paper type: Research paper

*Corresponding author: nadiaharyono@unesa.ac.id

Received: July 07, 2019; Accepted: January 09, 2020; Published: January 16, 2020

Cite this document: Afriani, T. \& Asandimitra, N. (2020). Determinants of Customer Preference to Save in Islamic Bank. Al-Uqud: Journal of Islamic Economics, 4(1), 1-17. doi: http://dx.doi.org/10.26740/al-uqud.v4n1.p1-17

Copyright $@$ 2020 , Al-Uqud: Journal of Islamic Economics

http://journal.unesa.ac.id/index.php/jie 


\begin{abstract}
Abstrak: Semakin meluasnya penggunaan produk dan instrumen syariah memberikan dorongan kepada masyarakat untuk menyimpan dana di bank syariah. Penelitian ini bertujuan untuk mengetahui pengaruh literasi keuangan, bagi hasil, pengetahuan nasabah, gender, umur, pendidikan, pendapatan terhadap keputusan menabung. Jenis penelitian kuantitatif dengan metode non-probabilitas sampling teknik snowball sampling dan purposive sampling untuk mendapatkansampel 230 responden. Objek penelitian adalah nasabah bank syariah di Kota Surabaya. Data diperoleh dengan menyebarkan kuesioner secara online dan offline berisi 41 item pernyataan dan pertanyaan. Teknik analisis data menggunakan analisis regresi linier berganda dengan IBM SPSS 18. Hasil penelitian, literasi keuangan nasabah berada pada kategori sedang yakni 72,1\% dan menjadikannya berpengaruh karena tingginya tingkat literasi keuangan mempengaruhi kemampuan untuk mengelola keuangan dan memutuskan menabung serta bagi hasil berpengaruh karena tingginya tingkat bagi hasil akan menimbulkan ketertarikan responden untuk menabung di bank syariah.
\end{abstract}

Kata kunci: Pengetahuan nasabah; Faktor demografi; Literasi keuangan; Bagi hasil; Keputusan menabung; Bank Syariah.

\title{
INTRODUCTION
}

The rise of sharia instruments and products in the financial macro strengthens the effect of the financial sectors with the real sector and creates harmonious relations between sectors. The spread use of sharia instruments and products, besides supporting the economic activities and public businesses also support the stability of the financial system and deduct speculative transaction in both financial and real sector.

The Financial Services Authority (OJK) estimated that someday the performance of commercial bank will be exceeded by sharia bank. The average growth of total number of accounts and saving within 2018 has reflected the impressive progress and achievement of sharia bank. Therefore, sharia bank is expected to create the significance of national financial for the sharia banking industry.

Based on Figure 1 (Appendix 1), the percentage of the total number of account sharia bank since early 2018 until November 2018 tends to increase around $-0,04 \% ;-0,08 \% ; 0,04 \% ; 0,12 \% ;-0,09 \% ;-0,06 \% ; 0,04 \% ; 0,21 \% ;-0,17 \% ; 0,09 \%$; and $-0,01 \%$ respectively. Conversely, the commercial bank are tend to slowly grow about $0,04 \% ; 0,08 \% ;-0,04 \% ;-0,12 \% ; 0,09 \% ; 0,06 \% ;-0,04 \% ;-0,21 \% ; 0,17 \%$; $0,09 \%$; and $0,01 \%$. The increasing percentage of the total number of account of sharia bank occured in March, April, June, Juli, August, and October that also reflects the total number of new customer also increasing.

In the data projection of 2010 by Statistics Indonesia, East Java becomes the second largest population in Indonesia around 39.292.972 people. Meanwhile, Surabaya as the capital city of East Java province contributes the biggest number of accounts and projected to increase more new branches of sharia bank.

Furthermore, Figure 2 (Appendix 2) shows the total population of Surabaya is higher than other provinces and cities in East Java, with the total number of 2.765.487 people. Malang follows Surabaya with the total number of 2.576.596

Copyright (C) 2020, Al-Uqud: Journal of Islamic Economics http://journal.unesa.ac.id/index.php/jie 
Tia Afriani, Nadia Asandimitra: Determinants of Customer Preference to Save in Islamic Bank

people and Jember around 2.430.185 people. Meanwhile, the region with the fewest population is Mojokerto with the total number of 127.279 people.

Besides being the region with the highest population, Surabaya also becomes the owner of the highest third-party funds between other cities and provinces in East Java. According to the Regulation of Bank Indonesia Number 10/19/PBI/2008, third-party funds or DPK is the bank's duty towards the public in rupiahs and foreign currencies.

In December 2016, a portion of the total savings of Surabaya reached up to IDR 85.854.605.000.000. The high saving accounts in Surabaya bring it as the owner of the highest third-party funds in East Java. Based on the data of Sharia Financial Statistic in August 2018 published by The Financial Services Authority (OJK), Surabaya is one of the cities which has the highest of third-party fund in East Java and becomes the third in Indonesia after Central Jakarta and South Jakarta.

Furthermore, Figure 3 (Appendix 3) informs about the DPK Surabaya that reach to IDR 14.196.000.000.000, in August 2018 and become the highest number among other cities and provinces in East Java. Thus, the increasing economic activities manifested by saving in sharia bank has escalated. According to this phenomenon, the researcher interested to analyze deeply about the decision of people on Surabaya to save their money on sharia bank that influenced by several factors such as financial literacy, profit sharing, customer knowledge, gender, age, education, and income.

Customer's acknowledgement about the benefit of saving in a financial institution or banking affects customer's high level of financial literacy. It was studied by Fry, Mihajilo, Russell, \& Brooks (2008); Beckmann (2013); Ianole (2014); and Gaisina \& Kaidarova (2017), but Reswari, Sudarto, \& Widiastuti (2018) found different result, that the financial literacy has not affected financial behaviour. Financial behaviour is relevant to customer's money management, including their saving behaviour (Xiao, 2008).

Profit-sharing Thayeb (2019) found the result that profit-sharing has a positive influence and the most influential factor on the interest of non-Muslim to become a customer of sharia bank. On the other hand, Perbawa (2015) also concluded profit sharing does not affect the total of mudaraba savings of bank which mean that the volume of mudaraba deposits on low level refers to the customers but not interest in saving on sharia bank.

Customer knowledge. Customers will use the bank services for the transaction if they know the bank's strengths. Nguyen, Rózsa, Belás, \& Belásová (2017) stated that knowledge has a significant effect on the saving decision. However, Ubaidi (2017) and Yahaya, Zainol, Osman, Abidin, \& Ismail (2019) stated a different opinion which does not affect the behaviour of consumers saving in using a sharia bank.

Gender. Mariyono (2013) and Rengarajan, Sankararaman, Kalyana Sundaram, Mohamed Rizwan, \& Mathew Paul Nibin (2016) revealed that gender significantly has to affect on saving decisions. However, Kowhakul (2016);

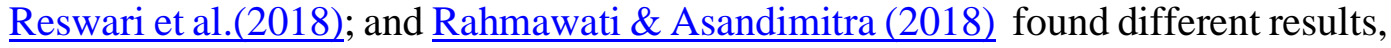
that gender did not affect customer's decision on saving. 
Age. The customer's awareness on the saving appears as the respondent gets mature. This opinion revealed by Mariyono (2013); Rengarajan et al.(2016); and Endalew (2019). Nevertheless, the result of the study of Kowhakul (2016); Reswari et al.(2018) and Rahmawati \& Asandimitra (2018) contradict the opinion before that the age level of people does not affect their the decision on saving.

Education. The high level of education of a person becomes the reason for respondents to have saving because since elementary school, they have been taught the importance of saving from school. Fry et al. (2008); Kowhakul (2016); and Nguyen et al. (2017) stated that someone's education affects saving decisions. But, Rahmawati \& Asandimitra (2018) revealed a different opinion that education does not affect saving behaviour.

Income. Someone who already has income might affect the amount of savings that they owned. This statement is supported by Rengarajan et al.(2016); Kowhakul (2016); Rahmawati \& Asandimitra (2018); Endalew (2019) they suggested that someone who already has income gets better to has saving decision. Otherwise, $\underline{\text { Mariyono (2013) }}$ and Ianole (2014) argued that income does not affect someone saving decisions.

\section{RESEARCH METHODS}

The quantitative data that used for this study are data in the form of numbers or qualitative data that converted into numbers. Meanwhile, the data sources, namely primary data obtained from the answers of 230 respondents. The data is collected by giving questionnaire to respondents. The data obtained by spreading the questionnaire online and offline contains 41 items of state ment and question.

Sampling in this study was conducted using non-probability sampling with snowball sampling and purposive sampling techniques with the following criteria (1) respondents are domiciled in the Surabaya; (2) respondents are sharia bank's customer in Surabaya, who already have savings account; and (3) respondents age is more than seventeen years old.

\section{RESULTS AND DISCUSSION}

At this stage, variables of financial literacy and customer knowledge must be tested for validity and reliability by scale application, because the indicators used in the questionnaire are questioned items. Based on validity and reliability test for question items indicate that indicators of financial literacy and customer knowledge have a reproducibility coefficient value $>0.90$ which means the indicators are valid. Meanwhile, the scalability coefficient value $>0.60$ which means the indicators are valid and thus indicators can be used as measuring instruments of financial literacy and customer knowledge.

The validity test for statement items is a bivariate correlation between the scores of items with total scores of items, that is comparing the value of $r_{\text {count }}$ with $r_{\text {table }}$ and degree of freedom $(\mathrm{df})=\mathrm{n}-2$, alpha 0.05. Based on the test indicate that $r$ count $>r_{\text {table }}$, then the items are said to provide a sufficient level of validity. Reliability testing of a construct or variables is said to be reliable if the value is Cronbach Alpha > 0.70. Based of the test shows the Cronbach value Alpha > 
0.70 , so it can be concluded that the construct of the question is given reliably which means the indicators are reliable and thus indicators can be used as measuring instruments the effect of financial literacy, profit sharing, and customer knowledge on saving decision in sharia banks.

The first classic assumption test is the normality test, the KolmogorovSmirnov (K-S) value is 0.655 and the significance is 0.784 . The significance value of $0.784>$ significance value of $5 \%$ or 0.05 , in which $\mathrm{H}_{0}$ is being accepted and can be concluded that the residuals are distributed normally. Then, the test of multicollinearity shows that the independent variable has a tolerance value $>0.10$ which means there are no correlations between independent variables with a value of more than $95 \%$. The VIF calculation results also show the same thing that the independent variable has a VIF value <10. It indicates that there is no multicollinearity between independent variables in the regression model. Meanwhile, the test of heteroscedasticity using scatterplot test, from scatterplot images can be seen that the data points spread above and below the value 0 , it can be concluded that there is no data homogeneity. From the test heteroscedasticity using Spearman's rho, there are no statistically significant variables that affect the dependent variable. It can be seen from the significance values above 0.05 or $5 \%$. This leads to the regression model that does not contain heteroscedasticity.

Based on F test calculations, the significant value shows 0,000 . Significant value $<0.05$ with the basis of decision making, namely the significant value of $5 \%$ or 0.05 . It means $\mathrm{H}_{0}$ is being rejected and $\mathrm{H}_{\mathrm{a}}$ is being accepted, thus financial literacy, profit sharing, customer knowledge, gender, age, education, and income affect saving decisions. The statistical results are in appendix 4.

Whereas, the calculation of the t-test in appendix 5 shows that there are only two independent variables that affect the dependent variable, i.e. financial literacy and profit-sharing. Because the significance value is $<0.05$, and there is multiple linear regression of equation models, obtained:

$\mathrm{Y}=0,955+0,548 \mathrm{X}_{1}+0,192 \mathrm{X}_{2}+e$

The Adjusted $R$ Square of 0.339 means the independent variable can explain $33.9 \%$ of the dependent variable. Meanwhile, $66.1 \%$ is explained by other variables outside of the independent variables in the study such as social effect, consumption by Ianole (2014); number of earning members of the family by Babiarz \& Robb $\underline{\text { (2014) }}$ and Rengarajan et al.(2016); marital status by Chua, Kiong, Villa, \& Paguta, (2016); financial self-efficacy by Rahmawati \& Asandimitra (2018); and sharia product attribute, insaniyyah promotion by Indriastuti \& Anwar (2018).

\section{The Effects of Financial Literacy on Saving Decision}

Based on the results, financial literacy affects the saving decision. Thus, the more high acknowledgement of the importance of saving in a financial institution or banking affected by the high level of financial literacy. Besides that, the respondents understand and acknowledge the usefulness of saving for the future and be more careful about managing their funds. Financial Literacy based on Planned Behavior Theory by Ajzen \& Fishbein (1977) explain a person's intention of behaving. Planned Behavior Theory states that someone takes action because there are an intention and purpose to do it. The important factors in determining intention are 
subjective norms, attitudes, and perceptions of behavioural control (Ajzen, 1991). Therefore, the higher financial literacy will result in better funds managing, the respondents decided to save their money or funds on financial institutions or banks.

Financial literacy is the knowledge to manage finance in decision making (Chen \& Volpe, 1998). From the definition, financial literacy is divided into four indicators, specifically personal financial management, savings, insurance, and investment. The level of financial literacy is classified into three groups, namely less than $60 \%$ (low), between $60 \%$ to $80 \%$ (medium) and more than $80 \%$ (high). The results of respondents answers regarding financial literacy using ten items of questions implies the medium level of financial literacy of sharia bank customers in Surabaya City. The medium level of customer's financial literacy reflects their high awareness about managing their finances properly.

Also, from the respondents' answers to the 10 items of questions used to measure the effect of financial literacy on saving decisions, four indicators are being used: consumption, savings, insurance funds, and investment. The highest value obtained on item X1.1 "I bought the items that I needed" which is 3.59 and included as the high category. Furthermore, the respondents who are customers of sharia bank in Surabaya in terms of financial literacy, especially personal financial management, and consumption are more concerned with buying goods based on their needs rather than discounts, desires or brand of the goods.

The results of the study stating that the high level of financial literacy also heightened the awareness of the importance of saving activities in financial institutions, namely banks supported by the research of Fry et al.(2008); Beckmann (2013); Ianole (2014); and Gaisina \& Kaidarova, (2017).

\section{The Effects of Profit-Sharing on Saving Decision}

Based on the results, profit sharing affects the saving decision. This means the profit-sharing system implemented by sharia banks, namely by dividing the income according to Islamic law and hadith attract the respondents to decide on becoming the customers of sharia banks and conduct savings activities. Profit-sharing based on Planned Behavior Theory by Ajzen \& Fishbein (1977) states that the high level of profit-sharing which is a system for profit sharing granted by two or more parties on agreements and mutual ties in conducting business activities will be a public interest in deciding to save in sharia banks.

This is supported by the results of respondents' answers regarding profitsharing by using three items of statements from that measure the effect of profit sharing on saving decision resulting the highest value on item X2.2 "profit-sharing system gives confidence in the fairness of profit sharing" which is equal to 3.26 and included as the high category. Moreover, the research respondents believe that the profit-sharing system will provide benefits in the form of fair profit-sharing. The profit-sharing system implemented by sharia banks is the reason why people become sharia bank customers and profit-sharing affects a community-saving decision. The results of the study stated that profit-sharing affects the decision of customers in sharia banks on saving, it is supported by several researchers who discovered similar results (Thayeb, 2019). 


\section{The Effects of Customer Knowledge on Saving Decision}

The results of the study implies that customer knowledge does not affect saving decisions. It means that the customer's knowledge of information about sharia banks is not the reason for respondents to become their customers. At a general level, knowledge can be defined as the information stored within the memory. The subset of total information relevant to consumers functioning in the marketplace is called consumer knowledge (Schiffman \& Kanuk, 2004). Customer knowledge does not affect saving decision because of the results of respondents' answers regarding customer knowledge using four items of questions shows the low level of knowledge of sharia bank customers in Surabaya. It was found that $56.55 \%$ of respondents answered the question correctly about the sharia banking contract, where the value was in the range of the low category of less than $60 \%$.

This is because most sharia bank customers are less familiar with the term contract in banks, where the terms use foreign languages. The term contract in sharia banking is a written agreement between sharia banks and customers that contains the rights and obligations of each party under sharia principles. Related to the contract which inform about sharia bank products, not all customers understand about it and reduce the level of customer knowledge.

In addition to the low level of customer knowledge, another support is from respondents' answers on the three items of statements used to measure the effect of customer knowledge on saving decisions. The highest obtained value on item X3.3 is "I am saving in sharia banks because the bank is trusted "that is equal to 3.26 and included in the high category. This shows that research respondents are more likely to save money in sharia banks because sharia banking is trusted as a financial institution and the term contract does not affect the customer's savings decision. The results of the study which show that customer knowledge does not affect the decision on saving in sharia banks are supported by Ubaidi (2017) and Yahaya et al., (2019).

\section{The Effects of Gender on Saving Decision}

The results of the study show that gender does not affect saving decisions. Thus, both men and women respondents have the same opportunity to save their money or funds. Gender-based on Planned Behavior Theory by Ajzen \& Fishbein (1977) explained that male-led households considered more competent in managing the funds rather than women. The chance for saving will be higher than consumption if the customer's funds management are good.

However, nowadays income source in a family is not only relied on men to work but also housewife who can also work based on their interest and have their income. In other words, there is no difference between men and women in making money or become a breadwinner. The non-effect of gender on saving decision is supported by the total number of respondents in the study that $56.5 \%$ or 130 respondents are female respondents. This means that women have the same opportunity to get income from work. Respondents can set aside a portion of their income to save money. 
The results of the study stating that gender does not affect saving decisions are following the research of Kowhakul (2016); Reswari et al. (2018) and Rahmawati \& Asandimitra (2018).

\section{The Effect of Age on Saving Decision}

The results of the study note that age does not affect the saving decision. It indicates that as long as the respondent still has income, both young and old, the respondents have the opportunity to manage their finances well. The financial management of respondents can do is to save income. Respondents save their money in a bank to fulfil sudden needs, maybe just in case or other purposes in the future.

Life Cycle Hypothesis Theory is an economic theory that explains how individuals save and spend their income on their lives. LCH was developed by Modigliani \& Brumberg (1954) in responding to everyone always tries to maintain the same level of consumption at all times and becomes the base for understanding how individuals behave and shows their reactions based on their age. Someone who gets older will get more effect on the saving decision. In this theory, the persons' orientation will tend to save money or funds purposing on having savings in old age or retirement.

The thing that causes non-affect is because, at a young age, someone already has a plan for their future by setting aside a portion of their income on saving to prepare their needs in retirement. Conversely, when they get older, respondents will prepare themselves to guarantee the needs of their families financially, both for children's needs, life savings, or inheritance.

The object of the research used the customers of sharia bank in Surabaya around 17 to 56 years old. The highest number of respondent age groups based on their age is under 25 years old with total of $58.7 \%$ or 135 respondents, while the lowest is the age above 56 years old with total of $1.3 \%$ or 3 respondents. It can be seen that the highest number of age groups is respondents who are in the score of 1 , which is under 25 years old, not the score of 5 , that is the above 56 years old, resulting in age does not affect saving decisions. The result of the study stating age does not affect the saving decision by Kowhakul (2016); Reswari et al. (2018) and Rahmawati \& Asandimitra (2018).

\section{The Effect of Education on Saving Decision}

The results of the study note that education does not affect the saving decision. It implies that the high level of education is not related to the respondents' saving decisions in financial institutions or banks. Education-based on Planned Behavior Theory by Ajzen \& Fishbein (1977)states that the high level of education makes a person has more information, with much information the financial management of the public will be better and they will decide to save money or funds. But in this study, education does not affect saving decisions.

Based on the table regarding the characteristics of respondents based on their education level into five groups by Ahmad \& Asghar (2002), it is found that respondents with elementary education are 1.7\%, Junior High School education is $2.2 \%$, Senior High School education is 50.4\%, Bachelor or Diploma is $45.7 \%$, and above Bachelor are $0 \%$. Although the average respondent is highly educated the 
educational variable is not influential due to the other factors outside the studied variable such as the motive in case there is an urgent need in the future. These factors were obtained from the results of interviews during the process of distributing the questionnaire, resulting in even though the respondents have low or high education, saving the decision is not affected. Because saving is a necessity and also the knowledge of saving is not only obtained from education in a formal environment, other than informally like parents or the environment might affect it as well. The results of the study testify that education does not affect saving decisions are supported by Rahmawati \& Asandimitra (2018).

\section{The Effect of Income on Saving Decision}

Based on the results of the study, it is stated that the income variable does not affect the saving decision. This means that the level of income of customers is not the reason for respondents on saving in sharia banks. The income-based on Planned Behavior Theory by Ajzen \& Fishbein (1977) states that high levels of income provide flexibility to manage finances and make someone decide to save. But in this study, the high level of income is not the reason of customers decided to save their money or funds on the sharia banks.

As shown on the results of the questionnaire, the percentage of the highest income range category is in the category of less than IDR 2,500,000 as much as $53.9 \%$ and the lowest income is above IDR 7,500,000 as much as $2.6 \%$. The average respondent is under 25 years old, around 135 respondents. This affects the number of respondents earning under IDR 2,500,000. The average respondent is a student whose income comes from their parent's pocket money and employees in a shopping centre with a salary below the regional minimum wage. The theoretical framework which stated the high level of income effects saving decision is not working for this case. It is because the average respondent has the range income of score 1 that equal to less than IDR 2,500,000.

Besides, from the results of a brief interview during the questionnaire distribution process to the respondents, it was found that high-income respondents which in the range of three (IDR 5,000,001 - IDR 7,500,000) and four (above IDR $7,500,000)$ were not reluctant to carry out consumptive activities. Through the statements about consumption in the financial literacy variable, respondents with high income evenly agree to buy goods based on discounts, desires, or brands. This proves that high-income respondents are more consumptive than respondents with moderate or low income. Therefore, income does not affect saving decisions that supported the previous studies by Mariyono (2013) and Ianole (2014).

\section{CONCLUSION}

Based on the result of the analysis and discussion described in the previous chapter, it can be concluded that: (1) financial literacy affects saving decision of the sharia bank in Surabaya; (2) profit sharing affects saving decision of the sharia bank in Surabaya; (3) customer knowledge does not affect saving decision of the sharia bank in Surabaya; (4) gender does not affect saving decision of the sharia bank in Surabaya; (5) age does not affect saving decision of the sharia bank in Surabaya; (6) education does not affect saving decision of the sharia bank in Surabaya, and 
(7) income does not affect saving decision of the sharia bank in Surabaya. Based on the result of the research, the further research might considered to employ other variables, such as social influence, consumption, work, family, and services.

\section{REFERENCES}

Ahmad, M., \& Asghar, T. (2002). Estimation of Saving Behaviour in Pakistan Using Micro Data. The Lahore Journal of Economics, 9(2), 73-98. https://doi.org/10.35536/lje.2004.v9.i2.a4

Ajzen, I. (1991). Theory of Planned Behavior. Journal Organizational Behavior and Human Decision Processes, 50(2), 179-211. https://doi.org/10.1016/0749-5978(91)90020-t

Ajzen, I., \& Fishbein, M. (1977). Attitude-Behaviour Relations: A Theoretical Analysis and Review of Empirical Research. Psychological Bulletin, 84(5), 888-918. https://doi.org/10.1037/0033-2909.84.5.888

Babiarz, P., \& Robb, C. A. (2014). Financial Literacy and Emergency Saving. Journal of Family and Economic Issues, 35(1), 40-50. https://doi.org/10.1007/s10834-013-9369-9

Beckmann, E. (2013). Financial Literacy and Household Savings in Romania. Numeracy, 6(2), 1-22. https://doi.org/10.5038/1936-4660.6.2.9

BPS (Statistics of Jawa Timur Province). (2018). Jawa Timur Province in Figures 2018.

Surabaya. https://jatim.bps.go.id/publication/2018/08/16/9999b727d316c006ee2fd7e7/ provinsi-jawa-timur-dalam-angka-2018.html

Chen, H., \& Volpe, R. P. (1998). An Analysis of Personal Financial Literacy Among College Students. Financial Services Review, 7(2), 107-128. https://doi.org/10.1016/s1057-0810(99)80006-7

Chua, N. E. A., Kiong, S. K. L., Villa, K. H. M., \& Paguta, R. B. (2016). A Tobit Analysis of the Determinants and Potentials of Savings in the Case of Payatas Households. Information Management and Business Review, 8(3), 47-57. https://doi.org/10.22610/imbr.v8i3.1331

Endalew, B. (2019). Determinants of Households Saving Capacity and Bank Account Holding Experience in Ethiopia: The Case of Dessie Zuria Woreda. Journal of Economics and Sustainable Development, 10(5), 1-16. https://doi.org/10.7176/JESD

Fry, T. R. L., Mihajilo, S., Russell, R., \& Brooks, R. (2008). The Factors Influencing Saving in a Matched Savings Program: Goals, Knowledge of Payment Instruments, and Other Behavior. Journal of Family and Economic Issues, 29(2), 234-250. https://doi.org/10.1007/s10834-008-9106-y

Gaisina, S., \& Kaidarova, L. (2017). Financial Literacy of Rural Population as a Determinant of Saving Behavior in Kazakhstan. Rural Sustainability Research, 38(333), 32-42. https://doi.org/10.1515/plua-2017-0010

Ianole, R. (2014). An Empirical Exploration of Mental Representations in the Individual Saving Decision Process. International Journal of Applied Behavioral Economics, 3(3), 48-63. https://doi.org/10.4018/ijabe.2014070104

Indriastuti, H., \& Anwar, A. (2018). Effect of Sharia Product Attributes and 
Tia Afriani, Nadia Asandimitra: Determinants of Customer Preference to 11 Save in Islamic Bank

Insaniyyah Promotion that is Conducted By Sharia Bank Toward NonMuslims' Decision to Become a Customer. In The 2018 International Conference of Organizational Innovation Volume 2018, KnE Social Sciences (Vol. 3, pp. 1067-1075). https://doi.org/10.18502/kss.v3i10.3449

Kowhakul, M. (2016). Personal Factors Affecting to the Saving Behavior of People in Bangkok Metropolitan Region, Thailand. In 25th International Academic Conference, OECD Headquarters, Paris (pp. 277-287). https://doi.org/10.20472/iac.2016.025.036

LPS (Indonesia Deposit Insurance Corporation). (2019). Deposit Statistics of Commercial Banks for 2018. Jakarta. https://lps.go.id/data-distribusisimpanan/-/asset_publisher/eN56/content/distribusi-simpanan-bank-umumperiode-november-2018

Mariyono, J. (2013). Determinants of Customers in Selecting Sharia Banking System for Saving in East Java - Indonesia. Journal of Economics, Business, and Accountancy $\quad$ Ventura, 16(3), 457-472. https://doi.org/10.14414/jebav.v16i3.225

Modigliani, F., \& Brumberg, R. (1954). Utility Analysis and the Consumption Function: An Interpretation of Cross-Section Data. New Brunswick: Rutgers University Press. https://doi.org/10.7551/mitpress/1923.003.0004

Nguyen, T. A. N., Rózsa, Z., Belás, J., \& Belásová, L'. (2017). The Effects of Perceived and Actual Financial Knowledge on Regular Personal Savings: Case of Vietnam. Journal of International Studies, 10(2), 278-291. https://doi.org/10.14254/2071-8330.2017/10-2/19

OJK (Financial Services Authority). (2018). Sharia Banking Statistic August 2018. Jakarta. $\quad$ https://ojk.go.id/id/kanal/syariah/data-dan-statistik/statistikperbankan syariah/Pages/Statistik-Perbankan-Syariah---Agustus-2018.aspx

Perbawa, A. (2015). Factors Affecting Mudaraba Deposits on Islamic Commercial Bank in Indonesia. SSRN Electronic Journal, 1-18. https://doi.org/10.2139/ssrn.2662912

Rahmawati, D., \& Asandimitra, N. (2018). The Influence of Demography, Social Environment and Financial Self-Efficacy toward Saving Behavior. In Advances in Social Science, Education and Humanities Research, Volume 222 2nd Social Sciences, Humanities, and Education Conference (SoSHEC 2018) (Vol. 222, pp. 102-106). https://doi.org/10.2991/soshec-18.2018.22

Rengarajan, V., Sankararaman, G., Kalyana Sundaram, M., Mohamed Rizwan, M., \& Mathew Paul Nibin, S. (2016). Influence of Demographic Variables on Saving Behaviour of Rural Households - A Study with Reference to Sriperumpudur, Chennai. Indian Journal of Science and Technology, 9(31), 1-7. https://doi.org/10.17485/ijst/2016/v9i31/97606

Reswari, A. D., Sudarto, \& Widiastuti, E. (2018). The Influence Of Financial Literacy Towards Financial Behavior. Journal of Research in Management, 1(2), 11-17. https://doi.org/10.32424/jorim.v1i2.28

Schiffman, L. G., \& Kanuk, L. L. (2004). Consumen Behavior (8th ed.). United State of America: Pearson Education International.

Thayeb, N. A. (2019). The Effect of Service and Profit Sharing on the Interests of Non-Musl im Customer to be Customer of Sharia Bank (Case Study At BRI 
12 Al-Uqud: Journal of Islamic Economics

Volume 4 Issue 1, January 2020

Syariah KC (Branch Office) Manado). Tasharruf: Journal Economics and Business of Islam, 3(2). https://doi.org/10.30984/tjebi.v3i2.787

Ubaidi, A. (2017). Factors Determine the Decision to Become a Customer in a Sharia Bank. Management and Business Review, 1(1), 1-6. https://doi.org/10.21067/mbr.v1i1.2129

Xiao, J. J. (2008). Applying Behavior Theories to Financial Behavior. In Handbook of Consumer Finance Research (pp. 69-81). Verlag New York: Springer. https://doi.org/10.1007/978-0-387-75734-6_5

Yahaya, R., Zainol, Z., Osman, J. H., Abidin, Z., \& Ismail, R. (2019). The Effect of Financial Knowledge and Financial Attitudes on Financial Behavior among University Students. International Journal of Academic Research in Business and Social Sciences, 9(8), 13-24. https://doi.org/10.6007/IJARBSS/v9-i8/6205 
Tia Afriani, Nadia Asandimitra: Determinants of Customer Preference to 13 Save in Islamic Bank

Appendix 1: Figure 1. Percentage of the Total Number of Account Sharia Bank Since January until November 2018 (Source: Indonesia Deposit Insurance Corporation, data processed by the author, 2019)

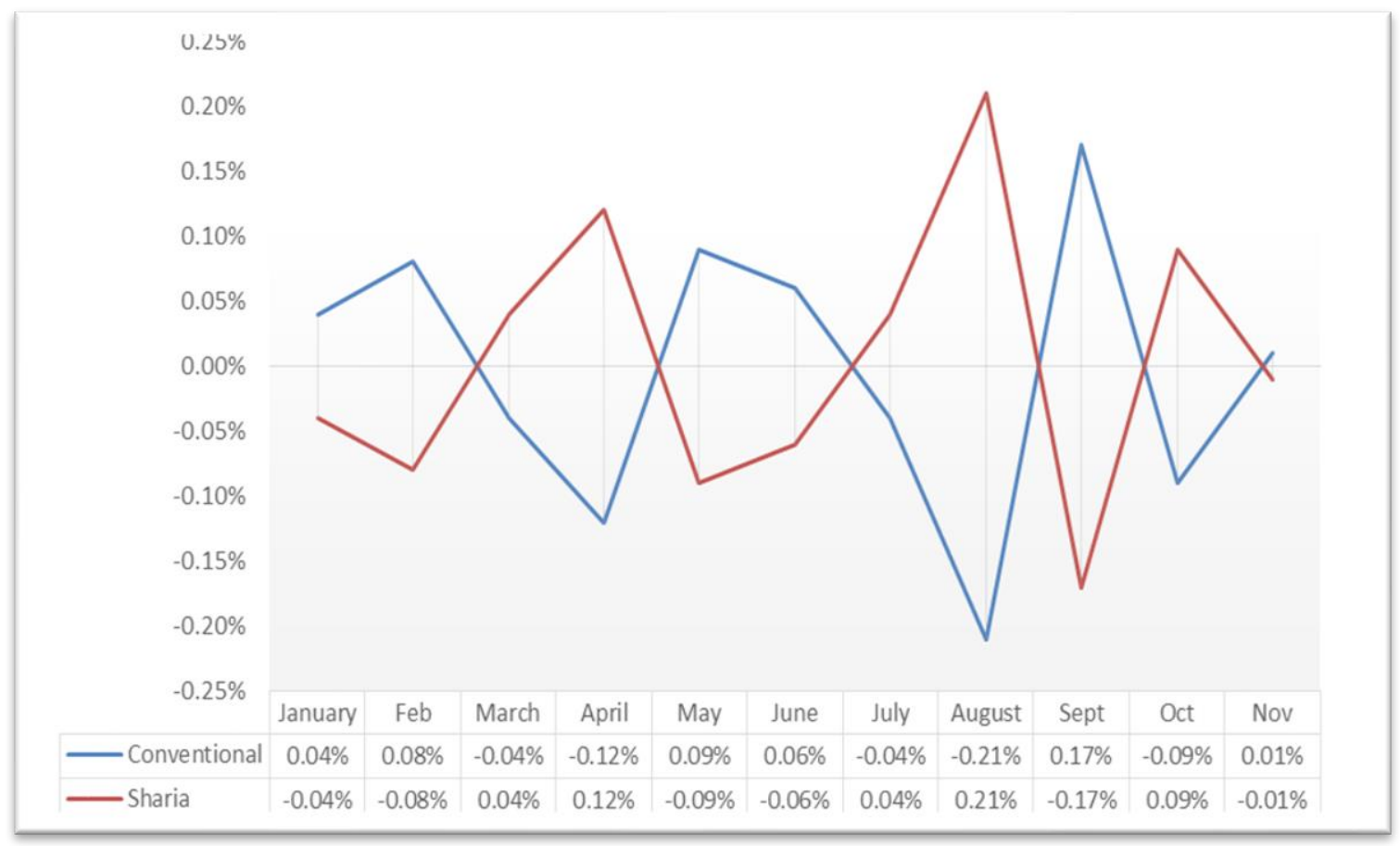


14 Al-Uqud: Journal of Islamic Economics

Volume 4 Issue 1, January 2020

\section{Appendix 2:}

Figure 2. Total Population According to City in East Java Province in 2017 (Source: Projection of Indonesian Population in 2010 until 2035, Statistics of Jawa Timur Province, data processed by the author, 2018)

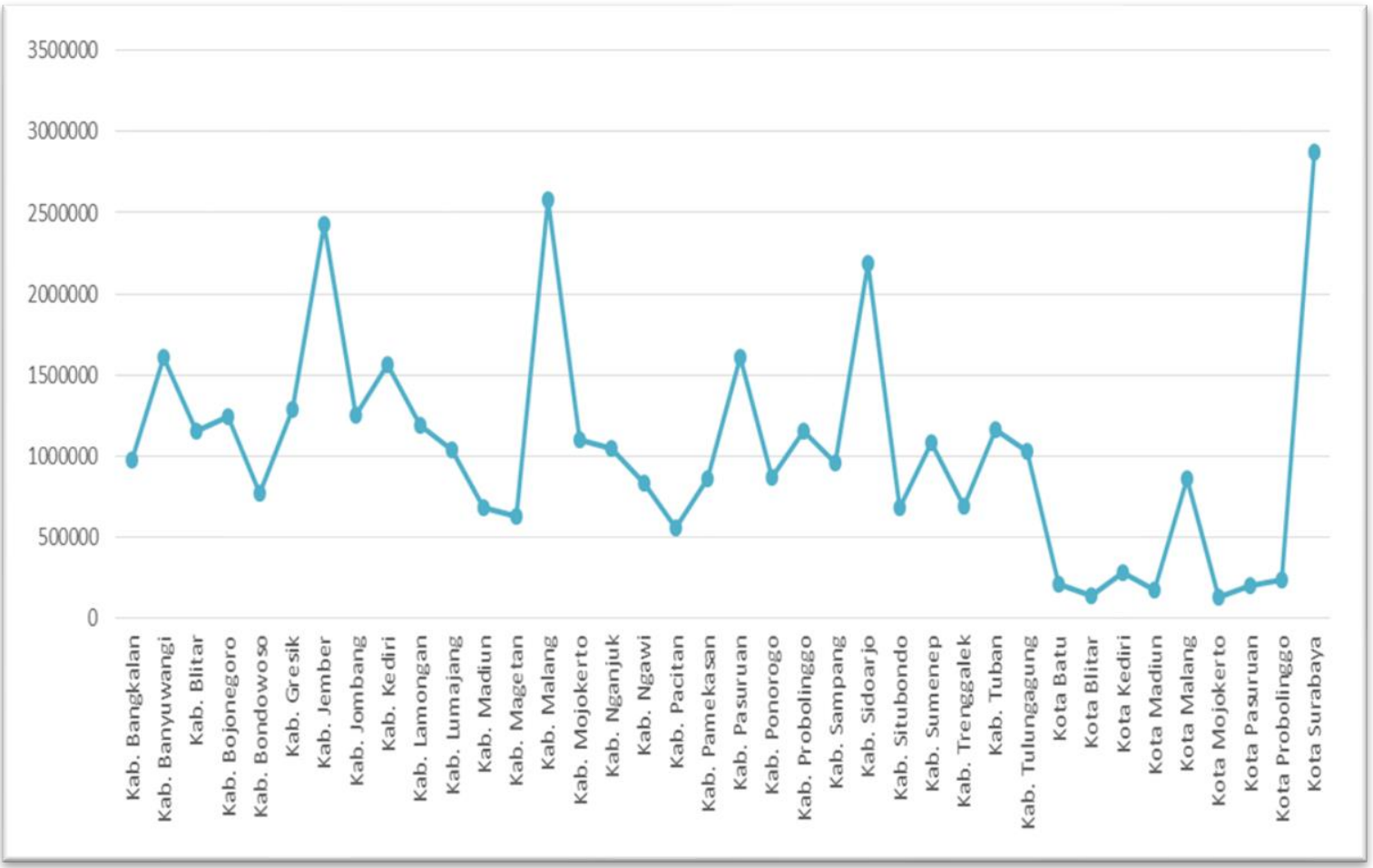


Tia Afriani, Nadia Asandimitra: Determinants of Customer Preference to 15 Save in Islamic Bank

\section{Appendix 3 :}

Figure 3. Third-Party Funds of Sharia Banks Based on City in East Java in August 2018 (Source: Financial Service Authority, data processed by the author, 2019)

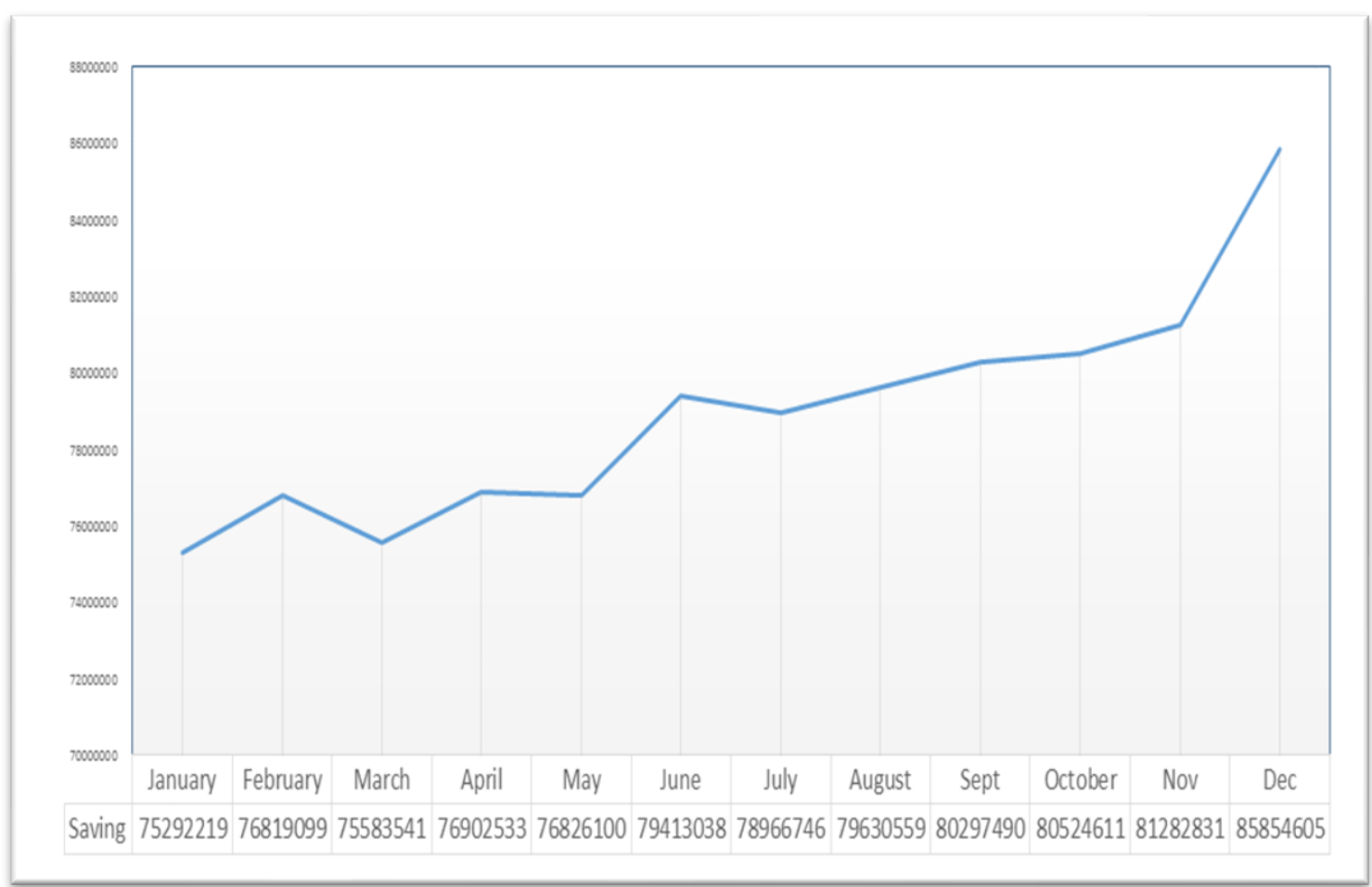


16 Al-Uqud: Journal of Islamic Economics

Volume 4 Issue 1, January 2020

Appendix 4. Result of the F Test

\begin{tabular}{|c|c|c|c|c|c|c|}
\hline \multicolumn{7}{|c|}{ ANOVA $^{b}$} \\
\hline & & Sum of Squares & Df & Mean Square & $\mathbf{F}$ & Sig. \\
\hline 1 & Regression & 16.559 & 7 & 2.366 & 17.789 & .000 \\
\hline & Residual & 29.522 & 222 & .133 & & \\
\hline & Total & 46.081 & 229 & & & \\
\hline
\end{tabular}

Source: Output of SPSS 18 (data processed by the author, 2019) 
Tia Afriani, Nadia Asandimitra: Determinants of Customer Preference to 17 Save in Islamic Bank

Appendix 5. Result of t-Test

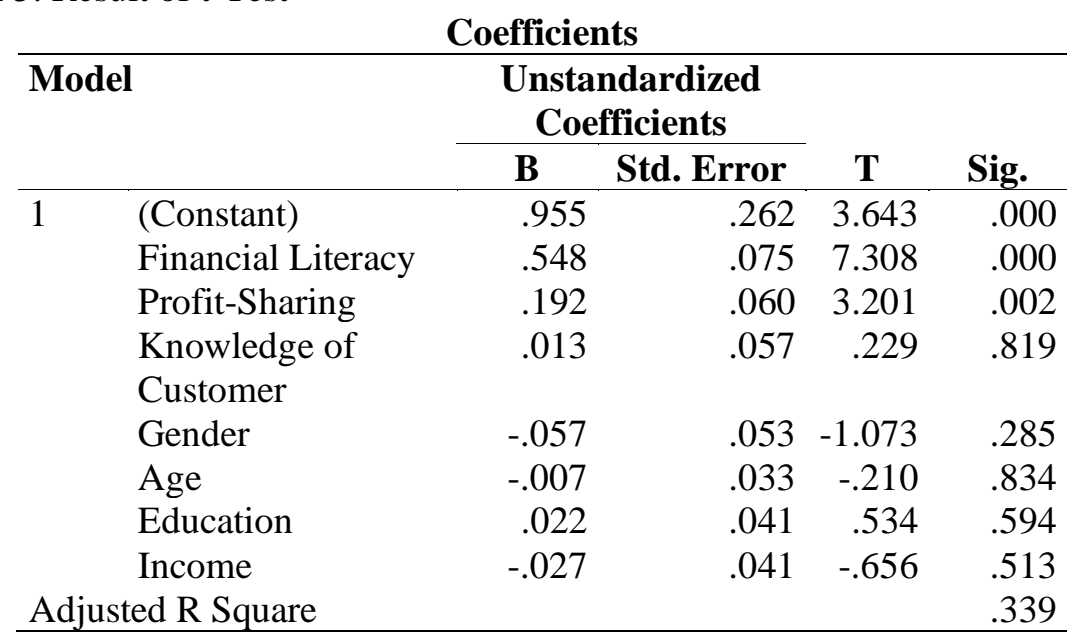

Source: Output of SPSS 18 (data processed by the author, 2019) 